\title{
ANALISIS KARAKTERISTIK PARAMETER HIDROLOGI AKIBAT ALIH FUNGSI LAHAN DI DAERAH SUKOHARJO MELALUI CITRA LANDSAT TAHUN 1997 DENGAN TAHUN 2002 \\ The Analysis of Hidrological Characteristics Parameter as The Effect of Landuse Changing Using Landsat Image From 1997 to 2002 in Sukoharjo District
}

\author{
Alif Noor Anna, Retno Woro Kaeksi, dan Wahyuni Apri Astuti \\ Fakultas Geografi Universitas Muhammadiyah Surakarta \\ J1. A. Yani Pabelan Tromol Pos 1 Kartasura, Surakarta 57102, \\ Telp. (0271) 717417 Psw. 151-153, Fax. (0271) 7155448 \\ email: alifnooranna@yahoo.co.id
}

\begin{abstract}
The Study, carried out Sukoharjo, deals with the effect of land function change from 1997 to 2002 toward the change of chosen hydrological parameters. The hydrological parameter constituses the coefficient runoff $(C)$, the extra soil water (id), and the amount of constant stream (Wa). The process of land function the change is searched by using landsat image composit RGB (Red Green Blue) 452. Meanwhile, the aims of the study are (1) to determine the types and distribution for the process of land function change, and (2) to analyze the change of coefficient value runoff (C), the extra soil water (Id), and the amount of constant stream (Wa) within the area of research. The result of the study shown that there are many types of land function change, which occurred in almost all the area of research except the one type coming from the river becoming wet/dry rice field/ residence/forest of which only occurred in Nguter sub district. The condition because of the straightening Bengawan Solo River in the sub district, cousequenly, the land function change proceses from the river into the land and vice versa. Moreover, of the 7 types of land function change in the area of research, the widest type of land function change covering the whole district is a change from forest/ horticulture/dry or wet rice field into residence. The effect of such a change has also caused a change in the characteristics of chosen hydrological parameter. Such a change can be seen from the value $C, I d$, and $W a$. Furthermore, the change can be clarified as follow: the value $C$ and $W a$ tend to rise while Id tends to decrease. This mean that the land function change has resulted in great abundant and decrease of water absorbed in the soil. In general, the availability of water source within the area can still be supplied from the seemingly increased constant stream. Such a condition might be caused by the ratio between the built land and the proportional open land of which about $>30 \%$ of the whole space.
\end{abstract}

Key words: land fuction change, hydrology parameter, coefficient runoff, the extra soil water, the amount of constant stream. 


\section{PENDAHULUAN}

Sumberdaya air merupakan salah satu potensi alam yang penting untuk dikelola dan diteliti. Hal ini karena sumberdaya air merupakan sumberdaya yang vital dan sekaligus sebagai lambang kemakmuran. Sampai saat ini masyarakat masih beranggapan bahwa pada wilayah yang mempunyai potensi sumberdaya air besar, maka umumnya wilayah tersebut merupakan wilayah yang makmur, dan sebaliknya bila wilayah yang potensi sumberdaya airnya kecil, maka wilayah tersebut akan miskin. Walaupun pada kenyataannya potensi sumberdaya ini sangat terkait dengan dari kondisi fisikal maupun kependudukan pada wilayah yang bersangkutan, seperti ketinggian tempat, letak lintang, geologi, iklim, topografi, vegetasi penutup, penggunaan lahan, maupun jumlah penduduk.

Hal demikian dimiliki pula oleh daerah Sukoharjo, antara lain mempunyai variasi kondisi permukaan lahan, topografi, curah hujan, maupun kependudukan. Hal ini tentunya akan berpengaruh pada sumberdaya air yang terdapat pada wilayah yang bersangkutan. Adapun gambaran variasi kondisi alam maupun kependudukan daerah ini, antara lain dapat terlihat dari penggunaan lahan, topografi, curah hujan dan pertumbuhan penduduknya. Variasi penggunaan lahan daerah ini berdasarkan Sukoharjo Dalam Angka (2004) masih terlihat bahwa sebagian besar berupa tanah sawah $(45,4 \%)$ yang diikuti dengan pekarangan $(33,4 \%)$, dan sisanya berupa tanah kering, kebun, hutan, dan tanah terbuka lainnya. Selanjutnya kondisi topografi daerah penelitian sebagian besar (96,25\%) merupakan dataran dengan kemiringan antara $0-15 \%$, dan hanya $0,80 \%$ yang mempunyai kemiringan $>40 \%$, sedangkan lainnya mempunyai lereng antara $15-40 \%$. Variasi jumlah curah hujan rata-rata tahunannya sebesar $1950,8 \mathrm{~mm}$, dan hanya mempunyai 3-4 bulan kering dan daerah ini mempunyai pertumbuhan penduduk rata-rata sebesar 1,3\%.

Selain itu, ternyata daerah Sukoharjo yang termasuk daerah pengembangan SUBOSUKA (Surakarta, Boyolali, Sukoharjo, dan Karanganyar) telah mendapatkan limpahan pembangunan fisik secara cepat. Hal ini sebagai konsekuensi wilayah yang saling berdekatan. Indikasi dari limpahan pembangunan itu salah satunya dapat dilihat dari perubahan penggunaan lahannya. Perubahan penggunaan lahan daerah ini umumnya dari tegalan dan sawah mengarah ke permukiman sekitar $81 \%$, diikuti tegalan menjadi industri dengan 7,3\%, dan lainnya (sarana transportasi dan olah raga) 1,15\% (Neraca Sumberdaya Alam (NSDA) Daerah Sukoharjo, 1999). Hal ini tentunya akan mengakibatkan pengurangan lahan terbuka, yang berarti akan mengurangi proses peresapan air hujan dalam tanah sebagai simpanan sumberdaya air pada wilayah yang bersangkutan.

Walaupun dari segi ekonomi menguntungkan, tetapi dari segi lingkungan terutama sumberdaya air akan berakibat pada pengurangan wilayah imbuhan air (reacharge area) ke dalam tanah. Hal ini karena pembangunan berarti melakukan penutupan lahan terbuka, sehingga curah hujan akan banyak yang menjadi aliran permukaan. Akibatnya koefisien aliran menjadi besar. Padahal pada sisi lain kebutuhan akan air semakin meningkat akibat adanya pertumbuhan penduduk, industri maupun variasi kegiatan sektor jasa.

Berdasarkan atas uraian di atas, maka penelitian ini akan menekankan pada analisis karakteristik parameter hidrologi antara lain berupa perubahan besaran koefisien limpasan, aliran mantap dan besaran air hujan 
yang meresap ke dalam tanah sebagai akibat dari perubahan penggunaan. Selain itu, juga mengidentifikasi variasi jenis perubahan alih fungsi daerah yang bersangkutan.

Telaah penelitian sebelumnya menyebutkan bahwa daerah yang mengalami perkembangan, biasanya ditandai dengan perkembangan pembangunan yang relatif cepat. Tanda-tanda perkembangan pembangunan ini lebih mudah dilihat dengan jelas terutama dari kenampakan fisik bangunannya. Kenampakan fisik tersebut umumya akan mengarah ke wilayah di sekitarnya berupa perubahan penggunaan lahan dari area yang terbuka (undevelopment area) menjadi area terbangun (development area). Umumnya perubahan tersebut menekan lahan pertanian menjadi lahan untuk pemukiman, industri dan jasa. (Soetikno, 1995).

Demikian pula pendapat Dini Purbani (2003) bahwa beralihnya fungsi lahan pertanian menjadi lahan terbangun saat ini banyak disebabkan oleh tekanan penduduk yang selalu menuntut ruang dalam aktivitasnya. Aktivitas tersebut antara lain berupa pembangunan industri dan perluasan urban yang berwujud pembangunan permukiman dan sarana umum. Pemanfaatan lahan yang berlebihan dengan tidak memperhatikan norma kelestarian lahan akan menyebabkan gangguan keseimbangan sumberdaya alam termasuk air. Hal tersebut sependapat dengan Muhsinatun (2000) yang mengatakan bahwa pembangunan untuk memenuhi sarana kegiatan masyarakat, umumnya pembuatan bangunan cenderung menghambat proses meresapnya air dalam tanah, yaitu dengan membentuk lahan terbangun berupa pembangunan pemukiman, industri, prasarana jalan dan yang terparah adalah penebangan hutan.
Hal ini berarti seluruh aktivitas terebut telah memperluas wilayah kedap air, sehingga menghambat proses meresapnya air hujan dalam tanah, sehingga penyusutan sumberdaya air tidak dapat terhindarkan.

Kondisi di atas ternyata telah terjadi di daerah Sukoharjo. NSDA Sukoharjo (1999) mendeskripsikan tentang dampak perubahan fisik akibat perkembangan kota Surakarta yang mempercepat meluasnya lahan terbangun di sekitar daerah Sukoharjo. Sasaran lahan terbangun ini telah menekan/mengurangi lahan pertanian seluas 45.500 ha. Sebagai akibat perubahan lahan tersebut Laviani, dkk (2003) telah meneliti di DAS Bodri, yang telah menunjukkan adanya indikasi peningkatan parameter hidrologi. Parameter tersebut antara lain terlihat dari peningkatan nilai koefisien aliran dari tahun ke tahun. Penelitian tentang perubahan penggunaan lahan tersebut dilakukan dari tahun 1992 sampai 2001. Adapun akibat dari pengurangan lahan hutan sebesar $-22,27 \%$ yang berubah menjadi lahan pertanian $(6,26 \%)$, permukiman (9,33\%), dan prasarana jalan $(6,73 \%)$ telah menaikkan koefisien runoff dari $7,7 \%$ menjadi $27,03 \%$.

Selanjutnya curah hujan yang jatuh di permukaan lahan akan mengalami berbagai macam proses, diantaranya penguapan melalui evapotranspirasi, meresap ke dalam tanah (infiltrasi), menjadi limpasan ataupun tersimpan dalam bentuk lengas tanah. Dalam hidrologi umumnya besarkecilnya limpasan dapat digunakan sebagai indikator terpenting dalam penyediaan sumberdaya air wilayah. Semakin kecil nilai limpasan permukaan, maka simpanan air dalam tanah semakin besar. Hal ini berarti sistem hidrologi dalam wilayah tersebut mempunyai kondisi yang baik. Oleh karenanya variabel permukaan lahan akan mempunyai pengaruh yang besar terhadap curah hujan yang akan tersimpan 
dalam tanah. Selain itu, penyediaan sumberdaya air wilayah dapat pula diperkirakan dengan menghitung koefisien limpasan (runoff). Adapun koefisien aliran adalah rasio limpasan dengan curah hujan dalam jangka waktu tertentu (Suyono, 1996). Secara empiris koefisien aliran dapat ditentukan dengan variabel input (hujan) dan variabel permukaan lahan daerah yang bersangkutan. Cara perhitungan empiris koefisien aliran diantaranya dari Cook's dan BransbyWilliam. Adapun variabel dalam penentuan koefisien aliran tersebut, banyak mempertimbangkan faktor hujan dan kemiringan lereng, tanah, vegetasi penutup lahan, serta simpanan permukaan lahan.

Selanjutnya metode koefisien aliran dapat digunakan untuk perkiraan aliran mantap (Wa). Cara perkiraan aliran mantap adalah dengan menghitung kehilangan air dan atau cadangan air permukaan dan air bawah permukaan. Adapun aliran mantap adalah aliran yang tersedia secara aman pada setiap waktu dalam rata-rata tahunan. Karakteristik Wa tersebut berfungsi sebagai penundaan dan memperlambat keberadaan air pada permukaan lahan suatu daerah (Hadi dan Endarmiyati, 1999).

Hasil dari penelitian ini diharapkan dapat memperoleh manfaat antara lain: a) dapat digunakan sebagai bahan pertimbangan untuk menyusun tata ruang daerah dengan mengetahui jenis dan persebaran penggunaan lahan, sekaligus sebagai bahan untuk penentuan langkah antisipasi pengelolaan lingkungan masa datang, dan b) untuk perencanaan dan pengelolaan sumberdaya air daerah penelitian.

\section{METODE PENELITIAN}

Metode yang digunakan adalah survei. Adapun untuk menentukan ketersediaan sumberdaya air wilayah menggunakan pendekatan hidrogeomorfologi dengan batas topografis. Selanjutnya dilakukan transformasi satuan wilayah dari satuan hidrogeomorfologi menjadi satuan administratif.

Perubahan penggunaan lahan daerah penelitian diperoleh dari penampakan Citra Landsat komposit RGB (Red-Green-Blue) 542 tahun 1999 dengan tahun 2002. Selanjutnya dilakukan cek lapangan untuk memastikan jenis alih fungsi lahan yang sebenarnya.

Adapun pengambilan sampling data primer yang berupa penentuan tekstur tanah ditentukan dengan cara proporsional random sampling. Dalam hal ini proporsinya sebanding dengan luas tiap jenis tanah daerah penelitian, selanjutnya penentuan tekstur tanah diambil secara acak.

Pemilihan parameter hidrologi akibat perubahan penggunaan lahan yang diukur dari indikasi perubahan air yang meresap ke dalam tanah dan nilai koefisien limpasan mengacu pada Suyono (1996) dan perkiraan banyak aliran mantap menggunakan Hadi dan Endarmiyati (1999).

\section{Teknik Perhitungan Data}

\section{Ketersediaan Air (Aliran Mantap)}

Ketersediaan air menggunakan fungsi temperatur tahunan dari rumus Mock (Maijerink, et al, 1994):

$\mathrm{T}=\left(\mathrm{H}-\mathrm{H}_{0}\right) 0,06+\mathrm{t}_{0}$

Dalam hal ini,

$\mathrm{T}=$ sebaran suhu $\left({ }^{\circ} \mathrm{C}\right)$,

$\mathrm{H}=$ sebaran ketinggian lokasi penelitian (m),

$\mathrm{H}_{0}=$ Ketinggian lokasi stasiun meteorologi $(\mathrm{m})$,

$\mathrm{t}_{0}=$ temperatur rerata tahunan stasiun meteorologi $\left({ }^{\circ} \mathrm{C}\right) \mathrm{Hh}$ " $[\mathrm{h} \mathrm{n}$ 
Besarnya evaporasi air permukaan ditentukan dengan cara Langbein:

Eo $=300+25 t+0,05 \mathrm{Ty}^{3}$

dalam hal ini,

Eo $=$ sebaran evaporasi air permukaan,

Ty $=$ sebaran rerata temperatur tahunan $\left({ }^{\circ} \mathrm{C}\right)$,

Evapotranspirasi aktual ditentukan dengan cara Turc-Langbein,

$$
E a=\frac{P}{\sqrt{0,9+\left(\frac{P}{E O}\right)^{2}}}
$$

dalam hal ini,

$\mathrm{Ea}=$ sebaran evapotranspirasi aktual $(\mathrm{mm} / \mathrm{th})$

$\mathrm{P}=$ sebaran hujan rerata tahunan $(\mathrm{mm} /$ th)

Eo $=$ sebatan evaporasi air permukaan $(\mathrm{mm} / \mathrm{th})$

Perhitungan ketersediaan aliran mantap ditentukan dengan rumus:

$\mathrm{Wa}=(1-\mathrm{c}) *(\mathrm{P}-\mathrm{Ea})$

Dalam hal ini,

$\mathrm{Wa}=$ ketersediaan air permukaan $(\mathrm{mm} /$

th)

$\mathrm{P}=$ curah hujan rerata tahunan $(\mathrm{mm} / \mathrm{th})$

$\mathrm{Ea}=$ evapotranspirasi aktual $(\mathrm{mm} / \mathrm{th})$

c $=$ koefisien limpasan Cook.

Perkiraan Air yang Meresap Dalam Tanab

$$
\begin{aligned}
& \mathrm{I}_{\mathrm{un}}=\mathrm{c} \mathrm{H} \mathrm{A} \mathrm{/} \mathrm{(1000)} \\
& \mathrm{I}_{\mathrm{d}}=\mathrm{c} \mathrm{H}(\alpha \mathrm{A}) /(1000)
\end{aligned}
$$

Dalam hal ini,

$\mathrm{I}_{\text {un }}=$ imbuhan alami pada saat undevelopment area $\left(\mathrm{m}^{3} /\right.$ tahun)

$\mathrm{I}_{\mathrm{d}}=$ imbuhan alami pada saat development area $\left(\mathrm{m}^{3} /\right.$ tahun $)$ c = koefisien limpasan,

$\alpha=$ persentase lahan terbuka terhadap luas wilayah,

$\mathrm{H}=$ curah hujan rata-rata tahunan $(\mathrm{mm})$,

A = luas wilayah $\left(\mathrm{m}^{2}\right)$.

\section{Penentuan Koefisien Limpasan}

Perkiraan nilai koefisian limpasan ditentukan dengan Cara Cook's. Cara ini menilai variabel permukaan lahan yang terdiri atas kemiringan, tanah (tekstur), vegetasi penutup, dan simpanan permuka-an (surface storage), yang selanjutnya dari masingmasing variabel dilakukan penjumlahan. Adapun cara penentuan koefisien limpasan ini dilakukan dengan pengolahan GIS pada setiap variabel yang diperkirakan berpengaruh.

Dalam penentuan ke empat variabel yang berpengaruh terhadap koefisien runoff ditentukan dengan teknik yang berbeda. Adapun penentuan tersebut seperti disajikan Tabel 1.

\section{Teknik Analisa Data}

Analisa data yang digunakan dalam penelitian ini adalah dengan matriks antara jenis alih fungsi lahan dengan parameter hidrologi. Selanjutnya matriks tersebut dianalisa secara deskriptif-komparatif.

\section{HASIL DAN PEMBAHASAN}

\section{Sebaran Alih Fungsi Lahan Daerah Penelitian}

Pengaruh penggunaan terhadap sistem hidrologi adalah menentukan besarnya curah hujan yang menjadi aliran atau besarnya air hujan yang meresap dalam tanah melalui infiltrasi Dalam hal ini pada lahan bervegetasi dan atau terbuka umumnya akan memperbesar kapasitas infiltrasi curah hujan ke dalam tanah, berarti menghambat aliran permukaan. 
Penggunaan lahan tersebut lebih jelas terdapat dalam Gambar 1, 2, dan 3.

Tabel 2 memperlihatkan karakter perubahan penggunaan lahan daerah penelitian. Tanda " $\checkmark$ " memperlihatkan frekuesi perubahan lahan pada masingmasing kecamatan di daerah penelitian.
Hasil yang diperoleh ternyata pola perubahan alih fungsi lahan daerah penelitian dapat dikelompokkan menjadi 7 macam yang tersaji pada Tabel 2. Dari ke tujuh macam tersebut, maka alih fungsi lahan yang paling banyak terjadi adalah dari jenis $\mathrm{Ht} / \mathrm{Pb} / \mathrm{Tg} / \mathrm{Sw}-\mathrm{Pk}$, selanjutnya diikuti Sw-Pb/Ht/Lhks/Tg, dan Tg/Kgd-

Tabel 1. Teknik Penentuan Skor Tiap Variabel Koefisien Runoff

\begin{tabular}{ll}
\hline \hline \multicolumn{1}{c}{ Variabel } & \multicolumn{1}{c}{ Teknik } \\
\hline Kemiringan & Rerata tertimbang \\
Tanah (tekstur), & Rerata tertimbang (jenis tanah) \\
Vegetasi penutup & Rerata tertimbang terhadap luas \\
Simpanan permukaan (surface storage) & Rerata tertimbang terhadap luas \\
\hline
\end{tabular}

Sumber: hasil analisis

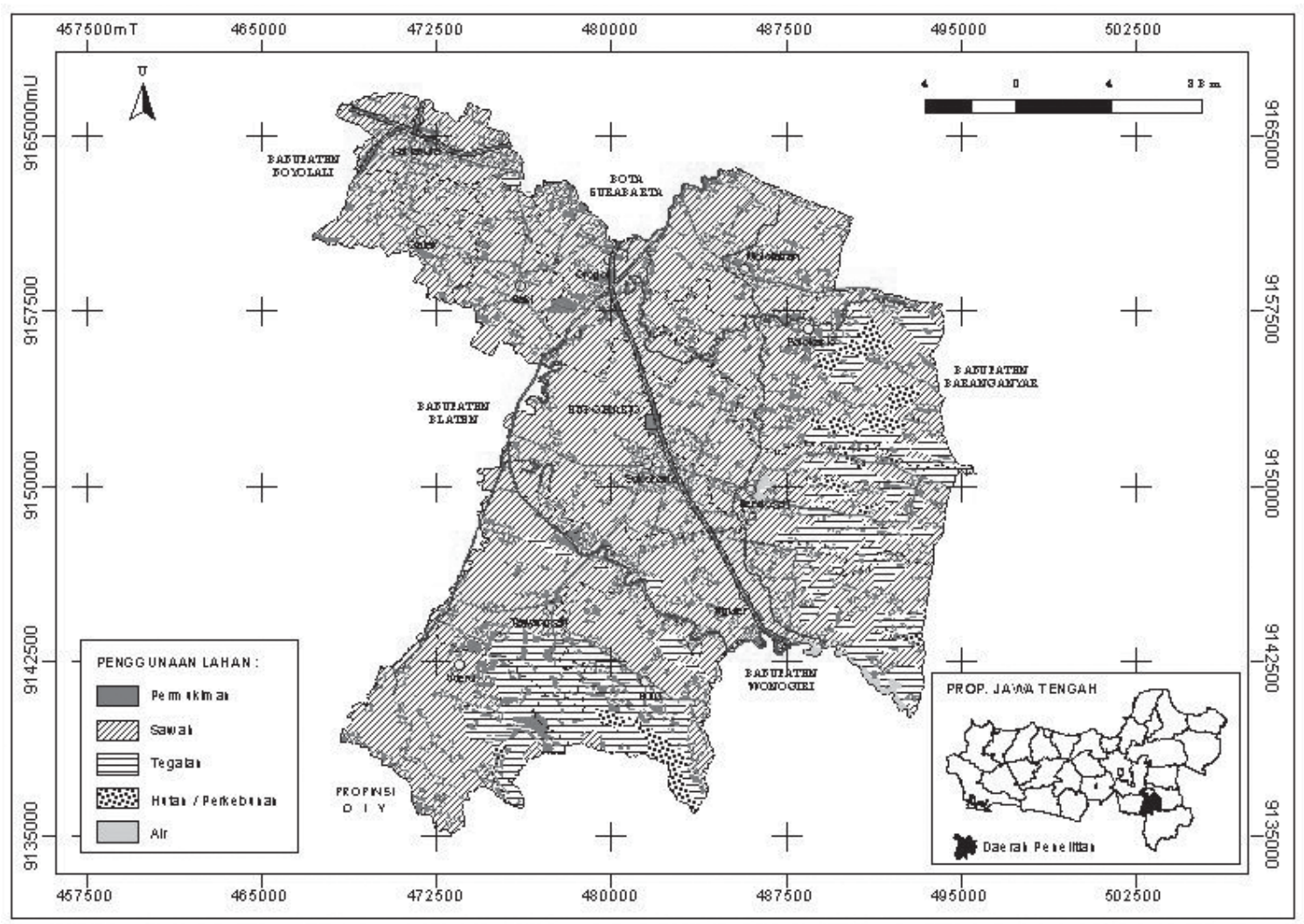

Sumber: hasil analisis

Gambar 1. Peta Penggunaan Lahan Kabupaten Sukoharjo Tahun 1997 


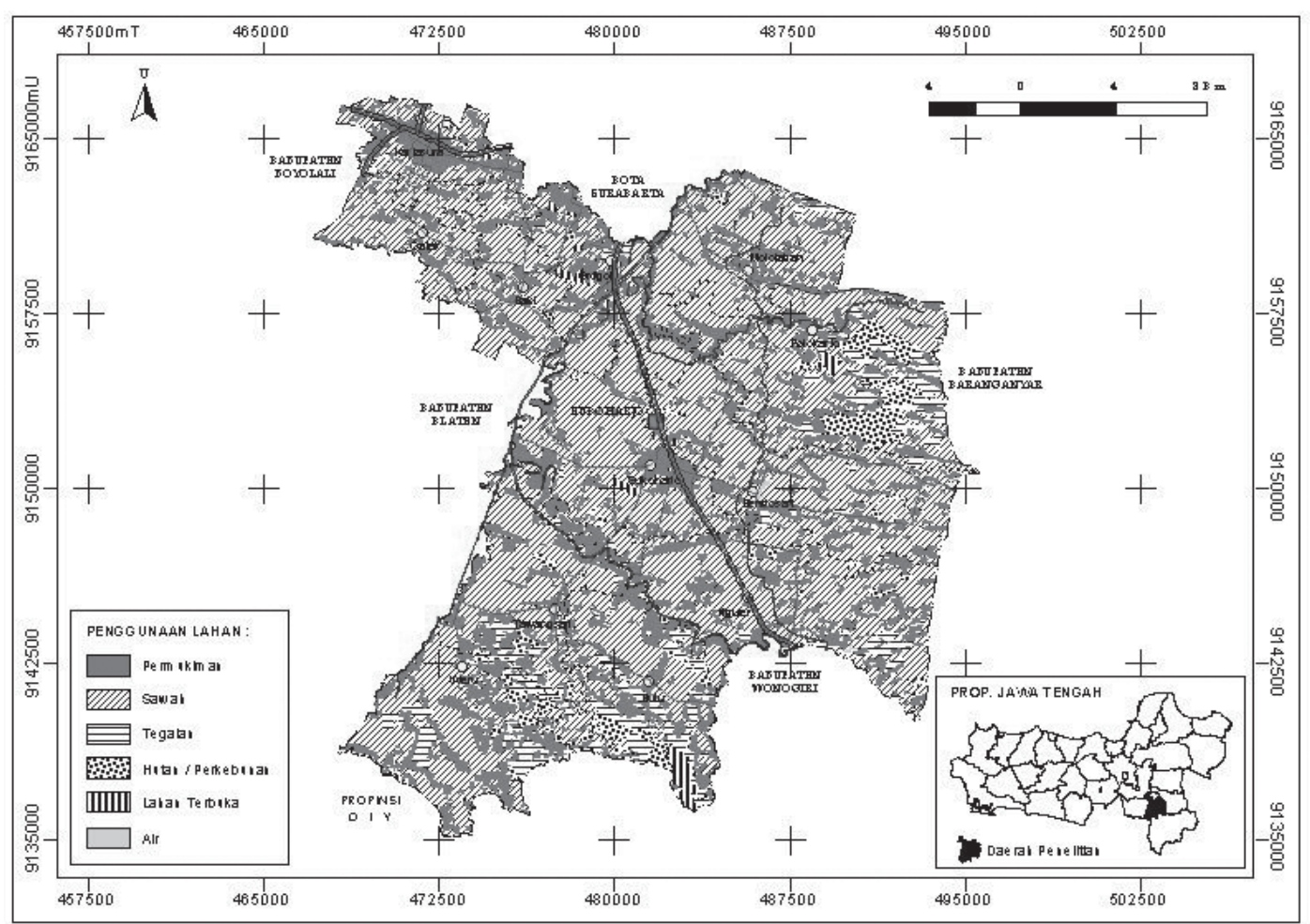

Sumber: hasil analisis

Gambar 2. Peta Penggunaan Lahan Kabupaten Sukoharjo Tahun 2002

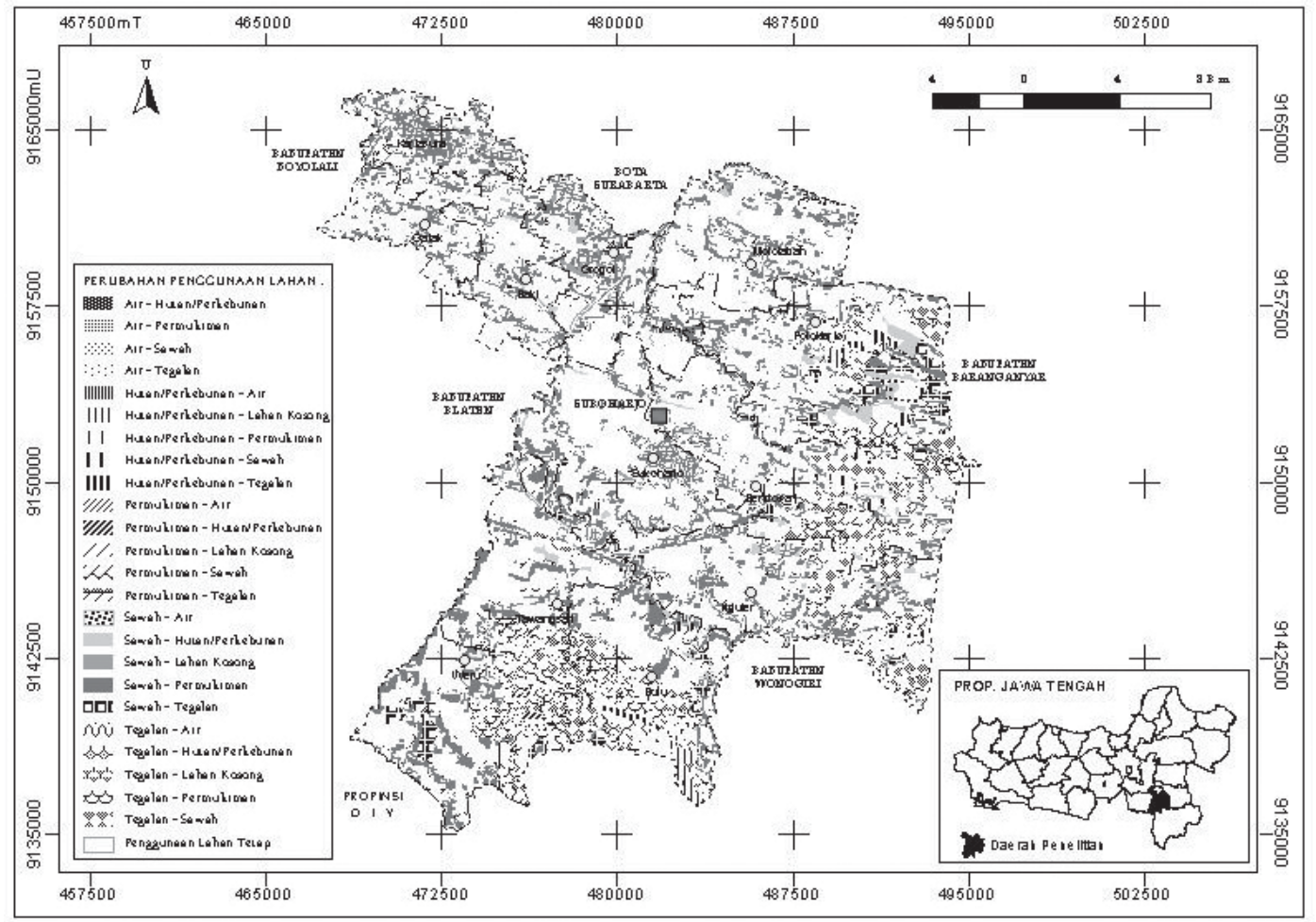

Sumber: hasil analisis

Gambar 3. Peta Perubahan Penggunaan Lahan Kabupaten Sukoharjo 
Lhks/Pb. Adapun yang paling lengkap terjadi 7 macam pola alih fungsi lahan adalah di Kecamatan Nguter, di sini juga terjadi alih fungsi lahan dari air-Ht/Sw/ $\mathrm{Pk} / \mathrm{Tg}$ atau sebaliknya. Hal ini terjadi karena daerah tersebut dilewati Sungai Bengawan Solo, yang saat itu telah dilakukan pelurusan sungai, sehingga yang dahulunya dari perairan menjadi lahan kosong yang lama kelamaan ada yang menjadi sawah, permukiman, tegalan atau bahkan menjadi hutan, dan demikian pula sebaliknya. Luas alih fungsi lahan tersebut tidak terlalu besar yaitu 27,7 ha. Adapun alih fungsi lahan terluas adalah dari $\mathrm{Ht} / \mathrm{Pb} /$ $\mathrm{Tg} / \mathrm{Sw}-\mathrm{Pk}$ sebesar $8.735,3$ ha $(18,71 \%)$.

\section{Karakteristik Perubahan Parameter Hidrologi Daerah Penelitian}

Sebagai konsekuensi dari alih fungsi lahan ini terhadap lingkungan ternyata telah terjadi pengurangan lahan terbuka menjadi wilayah terbangun. Alih fungsi lahan ini umumnya banyak menekan pada lahan pertanian maupun tegalan untuk dialihkan ke wilayah terbangun, baik untuk permukiman maupun pembangunan fasilitas pelayanan umum (pasar, kantor, industri, pelebaran jalan, dan lainnya). Secara hidrologis, kejadian tersebut berarti mengurangi wilayah resapan air (recharge area). Hal ini, tentunya simpanan air ke dalam tanah

Tabel 2. Pola Alih Fungsi Lahan Daerah Penelitian

\begin{tabular}{|c|c|c|c|c|c|c|c|c|}
\hline No & Kecamatan & $\begin{array}{c}\mathbf{A i r}- \\
\mathbf{H t} / \mathrm{S} w / \mathbf{P} \\
\mathbf{k} / \mathbf{T} \mathbf{g}\end{array}$ & $\begin{array}{c}\text { Tg/Kgd } \\
- \\
\text { Lhks } / \mathbf{P b}\end{array}$ & $\begin{array}{c}\mathbf{H t} / \mathbf{P b} / \mathbf{T g} \\
/ \mathrm{Sw}-\mathbf{P k}\end{array}$ & $\begin{array}{c}\text { Ht }- \text { Sw } \\
/ \text { Llks } / \mathrm{Tg} g\end{array}$ & $\begin{array}{c}\mathbf{H t} / \mathbf{P b} / \\
\mathbf{T g} \\
/ \mathbf{P k}- \\
\mathbf{a i r}\end{array}$ & $\begin{array}{c}\text { Sw - } \\
\mathbf{P b} / \mathbf{H t} \\
/ \text { Lhks / T g }\end{array}$ & $\begin{array}{c}\mathrm{Tg}- \\
\mathrm{Ht} / \mathrm{Sw}\end{array}$ \\
\hline 1 & Wenu & - & $\sqrt{1}$ & $\sqrt{1} \sqrt{2}$ & $\sqrt{1}$ & $\sqrt{ }$ & $\sqrt{4}$ & - \\
\hline 2 & Bulu & - & $\sqrt{ }$ & $\sqrt{1} \sqrt{1}$ & $\sqrt{1}$ & $\sqrt{ }$ & $\sqrt{ }$ & - \\
\hline 3 & Tawangs are & - & $\sqrt{4}$ & $\sqrt[4]{ }$ & - & $\sqrt{4}$ & $\sqrt{ }$ & $\sqrt{1}$ \\
\hline 4 & Sukoharjo & - & $\sqrt{4}$ & $\sqrt{ }$ & - & $\sqrt{ }$ & $\sqrt{4}$ & - \\
\hline 5 & Nortex & $\sqrt[H]{ }$ & $\sqrt{1}$ & $\sqrt{H} \sqrt{1}$ & $\sqrt{1}$ & $\sqrt[H]{4}$ & $\sqrt[H]{4}$ & $\sqrt[H]{ }$ \\
\hline 6 & Grogol & - & $\sqrt[4]{4}$ & 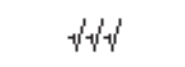 & $\sqrt{ }$ & $\sqrt[4]{4}$ & $\sqrt[4]{4}$ & $\sqrt[4]{4}$ \\
\hline 7 & Polokarto & - & $\sqrt{1}$ & $\sqrt{4}$ & $\sqrt[H]{4}$ & - & $\sqrt{4}$ & $\sqrt[H]{4}$ \\
\hline 8 & Mojolaban & - & $\sqrt[4]{ }$ & $\sqrt{ }$ & - & - & $\sqrt{1}$ & $\sqrt[H]{4}$ \\
\hline 9 & Grogol & - & $\sqrt[H]{ }$ & $\sqrt{4}$ & - & $\sqrt{ }$ & $\sqrt{ }$ & - \\
\hline 10 & Baki & - & 4 & $\sqrt[H]{ } \sqrt{2}$ & - & - & $\sqrt[H]{1}$ & $\sqrt[H]{ }$ \\
\hline 11 & Gatak & - & $\sqrt[4]{ }$ & $\sqrt{ }$ & - & - & $\sqrt{1}$ & - \\
\hline 12 & Kartasuza & - & $\sqrt{ }$ & $\sqrt{ }$ & - & - & $\sqrt[4]{ }$ & - \\
\hline
\end{tabular}

Sumber: Anna, et al (2006)

Keterangan:

- $\quad=$ Tidak ada alih fungsi lahan

$\sqrt{ }=$ Ada alih fungsi lahan

$\mathrm{Pk}=$ Permukiman

$\mathrm{Tg}=$ Tegalan

Lhks $=$ Lahan Kosong

$\mathrm{Ht}=$ Hutan

Kgd $=$ Komplek Gedung

$\mathrm{Pb}=$ Perkebunan

$\mathrm{Sw}=$ Sawah

Air $=$ Perairan 
cenderung berkurang dan selanjutnya berdampak pada sumberdaya air wilayah yang bersangkutan akan terganggu sirkulasinya.

Adapun dampak hidrologis yang diteliti menggunakan karakteristik perubahan 3 parameter. Parameter tersebut adalah nilai koefisien runoff (koefisien limpasan $=\mathrm{C}$ ), perkiraan jumlah aliran mantap(Wa), dan jumlah imbuhan air alami (Id).

\section{Perubahan Koefisien Runoff di Daerah Penelitian}

Hasil perhitungan nilai C secara keseluruhan disajikan pada Tabel 3. Terdapat 4 variabel penentu C, yaitu topografi, tanah, cover, dan surface storage. Namun diantara 4 variabel tersebut, maka variabel cover (penutup lahan) yang paling menentukan nilai C.
Tabel 3 memperlihatkan terdapat kecenderungan terjadi peningkatan nilai $\mathrm{C}$ antara tahun 1997 sampai tahun 2002. Kenaikan Nilai $C$ ini berarti persentase curah hujan yang menjadi limpasan semakin besar, dan sebaliknya persentase curah hujan yang meresap dalam tanah semakin kecil. Kondisi demikian diperkirakan karena adanya perubahan alih fungsi lahan yang cenderung mengurangi lahan resapan air.

Hal ini terlihat jelas dari data alih fungsi lahan yang terluas yaitu dari $\mathrm{Ht} / \mathrm{Pb} / \mathrm{Tg} /$ $\mathrm{Sw}-\mathrm{Pk}$. Selain itu, diperkuat dengan kondisi sosial-ekonomi dan kependudukan daerah penelitian yang terlihat meningkat pula. Dari segi sosial penduduk yang dicerminkan dari tingkat pendidikannya sebanyak $38,92 \%$ (pendidikan sedang) penduduk telah menyelesaikan pendidikan

Tabel 3. Perbandingan Koefisien Runoff Daerah Penelitian

Tahun 1997 dengan Tahun 2002 (dalam \%)

\begin{tabular}{|c|c|c|c|c|c|c|c|c|c|c|c|}
\hline \multirow{3}{*}{ No } & \multirow{3}{*}{ Kecamatan } & \multicolumn{8}{|c|}{ Cook's Table } & \multirow{2}{*}{\multicolumn{2}{|c|}{$C(\%)$}} \\
\hline & & \multicolumn{2}{|c|}{ Topografi } & \multicolumn{2}{|c|}{ Soil } & \multicolumn{2}{|c|}{ Cover } & \multicolumn{2}{|c|}{$\begin{array}{l}\text { Surface } \\
\text { Storage }\end{array}$} & & \\
\hline & & 1997 & 2002 & 1997 & 2002 & 1997 & 2002 & 1997 & 2002 & 1997 & 2002 \\
\hline 1 & Weru & 25 & 25 & 11 & 11 & 15 & 16 & 18 & 18 & 69 & 70 \\
\hline 2 & Bulu & 38 & 38 & 13 & 13 & 14 & 15 & 12 & 12 & 77 & 78 \\
\hline 3 & Tawangs ari & 30 & 30 & 14 & 14 & 15 & 16 & 18 & 18 & 77 & 78 \\
\hline 4 & Sukoharjo & 15 & 15 & 15 & 15 & 16 & 16 & 15 & 15 & 61 & 61 \\
\hline 5 & Nguter & 25 & 25 & 9 & 9 & 15 & 16 & 15 & 15 & 64 & 65 \\
\hline 6 & Bendos ari & 20 & 20 & 6 & 6 & 14 & 16 & 15 & 15 & 55 & 57 \\
\hline 7 & Polokatto & 20 & 20 & 7 & 7 & 14 & 15 & 12 & 12 & 53 & 54 \\
\hline 8 & Mojolaban & 20 & 20 & 6 & 6 & 15 & 16 & 15 & 15 & 56 & 57 \\
\hline 9 & Grogol & 10 & 10 & 13 & 13 & 17 & 19 & 18 & 18 & 58 & 60 \\
\hline 10 & B aki & 10 & 10 & 10 & 10 & 16 & 16 & 15 & 15 & 51 & 51 \\
\hline 11 & Gatak & 10 & 10 & 10 & 10 & 16 & 16 & 15 & 15 & 51 & 51 \\
\hline 12 & Kartosuro & 10 & 10 & 10 & 10 & 16 & 18 & 20 & 20 & 56 & 58 \\
\hline
\end{tabular}

Sumber: Anna, et al (2006) 
9 tahun (tamat SLTP). Adapun dari segi ekonomi ternyata mata pencaharian penduduk di daerah penelitian telah bergeser dari sektor pertanian ke sektor industri, perdagangan dan jasa sebesar 14,01\%. Selanjutnya dari kependudukan telah pula terlihat meningkat yaitu dari segi pertumbuhan penduduk naik sebesar 1,39\%/tahun dan kepadatan rata-rata meningkat sebesar 73 jiwa $/ \mathrm{km}^{2} /$ tahun.

\section{Perkiraan Air yang Meresap dalam Tanah (Id)}

Daerah penelitian saat ini ternyata telah terjadi perubahan yang kecenderungannya terjadi pengurangan lahan terbuka. Hal ini sebagai konsekuensi logis dari pertumbuhan penduduk yang diikuti dengan kemajuan pembangunan wilayah yang bersangkutan. Pertumbuhan penduduk ternyata telah mendorong aktivitas pembangunan, khususnya bidang permukiman, sehingga alih fungsi lahan tidak dapat terhindarkan. Akibatnya proses peresapan air dalam tanah semakin ber- kurang, sehingga jumlah simpanan air-pun mengecil. Adapun perubahan imbuh-an air (Id) diperlihatkan dalam Gambar 2.

Berdasarkan Tabel 4 dan Gambar 2 memperlihatkan bahwa daerah penelitian umumnya telah terjadi pengurangan resapan air dalam tanah. Pengurangan terbesar terjadi di Kecamatan Kartasura, sedangkan terkecil di Kecamatan Sukoharjo. Selain itu, ternyata terdapat 5 (lima) kecamatan lain yang jumlah perubahan resapan airnya cukup besar. Adapun kecamatan tersebut adalah Kecamatan Polokarto, Kecamatan Mojolaban, Kecamatan Grogol, Kecamatan Baki, dan Kecamatan Gatak. Hal ini mengingat bahwa kedua kecamatan tersebut (Kartasura dan Sukoharjo) termasuk wilayah yang mempunyai curah hujan yang tinggi yaitu antara $2000-2500 \mathrm{~mm} / \mathrm{th}$, sedangkan 5 kecamatan lain termasuk wilayah yang mempunyai curah hujan sedang yaitu antara $1500-2000 \mathrm{~mm} /$ th. Dengan demikian, pengurangan resapan air akibat perubahan penggunaan lahan sangat signifikan.

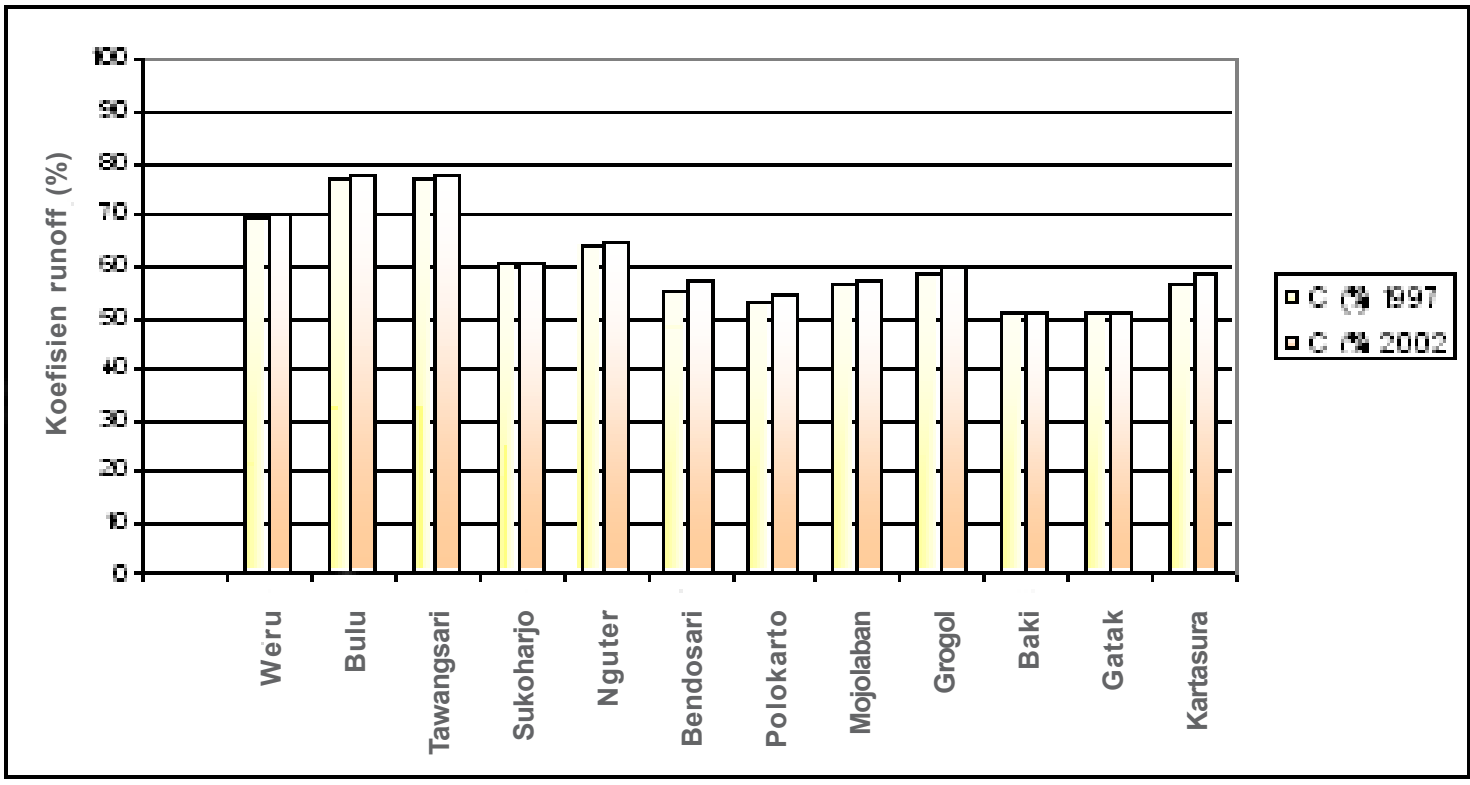

Sumber: hasil analisis

Gambar 1. Grafik Koefisien Runoff Kabupaten Sukoharjo

Tahun 1997 - 2002 
Tabel 4. Perbandingan Koefisien Runoff Daerah Penelitian

Tahun 1997 dengan Tahun 2002 (dalam \%)

\begin{tabular}{llrrr}
\hline \hline No. & Kecamatan & \multicolumn{1}{c}{ Id 1997 } & \multicolumn{1}{c}{ Id 2002 } & \multicolumn{1}{c}{ Perubahan } \\
\hline 1. & Weru & 351.301 & 263.240 & -88.061 \\
2. & Bulu & 792.851 & 687.693 & -105.158 \\
3. & Tawrangsari & 293.280 & 245.545 & -47.735 \\
4. & Sukohatjo & 25.197 & 11.901 & -13.295 \\
5. & Nguter & 3.642 .039 & 2.910 .119 & -731.919 \\
6. & Bendosari & 2.214 .335 & 1.827 .311 & -387.023 \\
7. & Polokarto & 10.222 .507 & 9.071 .816 & -1.150 .690 \\
8. & Mojolabar1 & 5.707 .997 & 4.809 .873 & -898.124 \\
9. & Grogol & 4.020 .852 & 3.045 .858 & -974.994 \\
10. & Baki & 7.312 .686 & 5.948 .103 & -1.364 .583 \\
11. & Gatak & 6.203 .648 & 5.102 .145 & -1.101 .503 \\
12. & Kartasuro & 7.400 .476 & 4.135 .788 & -3.264 .689 \\
\hline
\end{tabular}

Sumber: Anna, et al (2006)

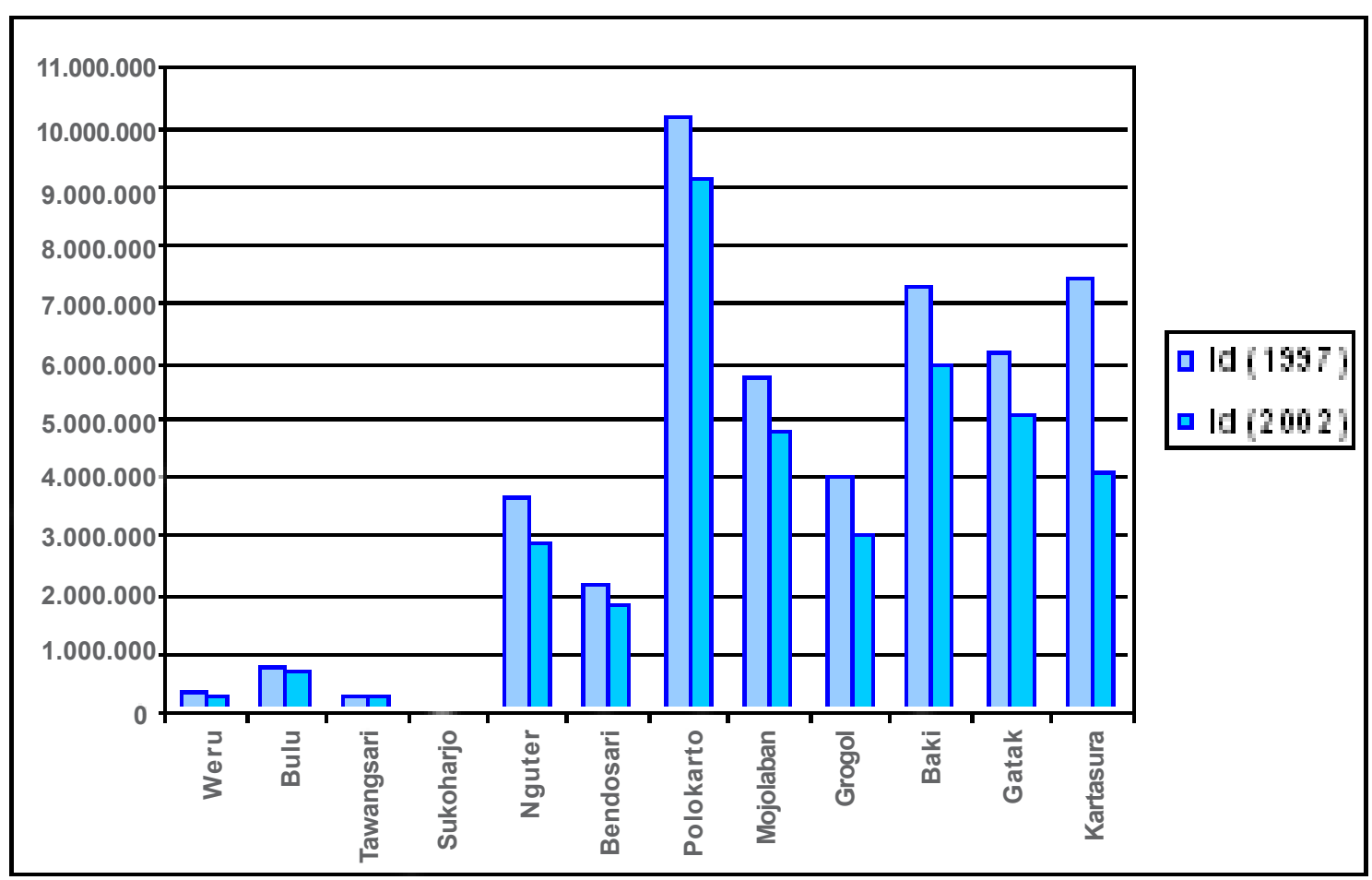

Sumber: hasil analisis

Gambar 2. Grafik Perubahan Imbuhan Air Tanah Alami (Id)

Kabupaten Sukoharjo tahun 1997 - 2002 
Pada kecamatan yang perubahan imbuhan air tanahnya mempunyai jumlah yang besar umumnya merupakan wilayah kecamatan yang berubah dari daerah rural ke urban. Kecamatan-kecamatan tersebut bukan hanya berfungsi sebagai pusat pemerintahan saja, tetapi juga sebagai wilayah yang telah berkembang menjadi daerah industri, perdagangan, dan jasa. Di samping itu, ternyata kecamatan tersebut berbatasan langsung dengan Kota Surakarta, sehingga cenderung ber-kembang menjadi daerah perkotaan. Adapula kecamatan yang mempunyai letak geografis yang strategis, seperti Kecamatan Kartasura. Kecamatan ini merupakan kota transit yang menghubungkan antar propinsi yaitu antara Kota Semarang-Solo-Yogjakarta. Adapun Kecamatan Grogol saat ini sudah dikembangkan menjadi Kota Satelit yang dikenal dengan "Solo Baru", sehingga wajar bila terjadi alih fungsi lahan yang sangat luas $(1,50 \%)$.

\section{Aliran Mantap (Wa)}

Ketersediaan aliran mantap (Wa) dihitung berdasarkan rumus 4. Selengkapnya hasil yang diperoleh disajikan pada Tabel 5 . Perhitungan Wa pada dasarnya mendasarkan pada selisih total curah hujan dengan limpasan terhadap total curah hujan dikurangi evapotranspirasi.

Gambar 3 memberi gambaran tentang besar perbedaan aliran mantap selama penelitian. Berdasarkan atas tabel dan gambar tersebut terlihat bahwa secara umum jumlah aliran mantap di daerah penelitian mempunyai kecenderungan meningkat. Kondisi tersebut disebabkan karena beberapa hal. Hal tersebut antara lain:(1) Seluruh daerah penelitian ternyata mempunyai jumlah curah hujan rerata yang tinggi (>1500 mm/tahun); (2) pengelolaan permukaan lahan baik, dalam arti lahan yang tertutup vegetasi masih proporsional dengan lahan yang terbangun, walaupun saat ini telah terjadi alih fungsi

Tabel 5. Ketersediaan Aliran Mantap (Wa) Kabupaten Sukoharjo

Tahun 1997 - 2002

\begin{tabular}{|c|c|c|c|}
\hline No & Kecamaitan & 项 $1997\left(\mathrm{~m}^{2}\right)$ & 15 a $2002\left(\mathrm{~m}^{2}\right)$ \\
\hline 1 & Wetu & 28885 & 29303 \\
\hline 2 & Bulu & 29328 & 29711 \\
\hline 3 & 'Tawangs ari & 28645 & 29017 \\
\hline 4 & Sukoharjo & 20571 & 20571 \\
\hline 5 & Nguter & 16838 & 17108 \\
\hline 6 & Bendos ari & 28744 & 29781 \\
\hline 7 & Polok atto & 31494 & 32094 \\
\hline 8 & Mojolabant & 23625 & 24047 \\
\hline 9 & Grogol & 16381 & 16948 \\
\hline 10 & Baki & 9600 & 9600 \\
\hline 11 & Gatak & 8421 & 8421 \\
\hline 12 & Kastasuxa & 11283 & 11686 \\
\hline
\end{tabular}

Sumber: Anna, et al (2006) 
lahan yang cukup besar; (3) sifat fisik tanah secara umum mem-punyai permeabilitas rendah (tekstur: lempung), sehingga daya resap air ke dalam tanah rendah; (4) jaringan sungai besar banyak melintasi daerah penelitian, sehingga persentase curah hujan yang menjadi limpasan cukup besar.

\section{Analisis Karakteristik Parameter Hidrologi Akibat Alih Fungsi Lahan Daerah Penelitian}

Hasil yang diperoleh ternyata nilai C umumnya mengalami peningkatan, kecuali Kecamatan Sukoharjo, Kecamatan Baki, dan Kecamatan Gatak. Peningkatan nilai $\mathrm{C}$ ini banyak disebabkan karena adanya alih fungsi lahan yang terjadi di daerah penelitian. Perubahan alih fungsi lahan di daerah penelitian umumnya berubah dari lahan terbuka menjadi lahan terbangun, ternyata telah mengakibatkan pengurangan lahan peresapan air. Akibat selanjutnya adalah pengurangan persentase curah hujan yang menjadi limpasan semakin besar.
Pengurangan lahan resapan air ini merupakan dampak langsung dari pertumbuhan penduduk, yang dalam hal ini penggunaan lahan tersebut banyak digunakan untuk permukiman. Terkait dengan pertumbuhan penduduk di daerah penelitian ternyata terdapat 6 (enam) kecamatan yang pertumbuhan penduduknya lebih dari $1 \%$ per tahun (termasuk klasifikasi sedang). Ke enam kecamatan tersebut adalah Kecamatan Sukoharjo, Kecamatan Mojolaban, Kecamatan Grogol, Kecamatan Baki, Kecamatan Gatak, dan Kecamatan Kartasura. Diantara ke enam kecamatan tersebut, maka pertumbuhan penduduk terbesar terdapat di Kecamatan Grogol (2,12\%). Hal ini karena kecamatan tersebut telah dikembangkan menjadi komplek permukiman baru dari Kota Surakarta, yang dinamakan "Solo Baru". Adapun kecamatan lain secara geografis umumnya berada di perbatasan langsung dengan Kota Surakarta, sehingga wilayah-wilayah tersebut tidak dapat menghindari terjadinya perluasan permukiman kota tersebut. Kecamatan

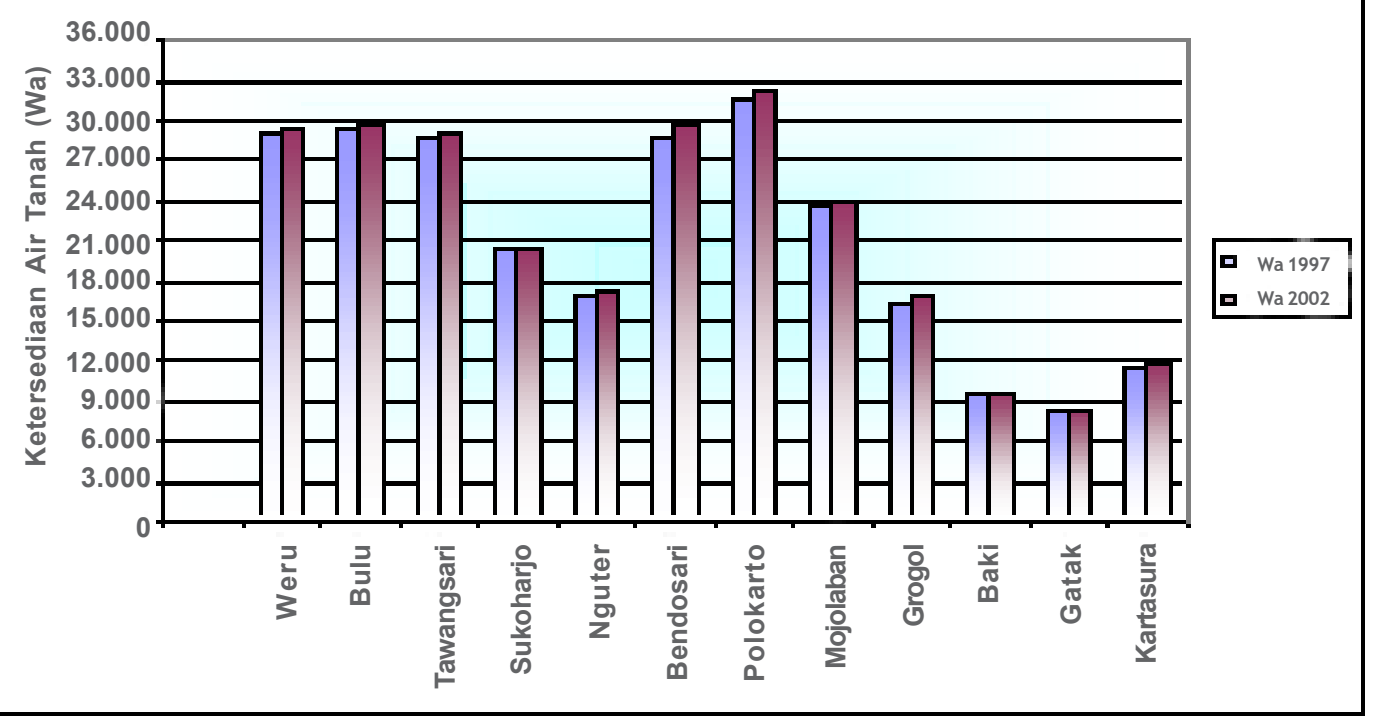

Sumber: hasil analisis

Gambar 3. Grafik Ketersediaan Aliran Mantap (Wa) Kabupaten Sukoharjo

Tahun $1997-2002$ 
Sukoharjo sendiri merupakan ibukota kabupaten, sehingga berfungsi sebagai pusat pemerintahan yang secara otomatis akan terjadi konsentrasi perluasan permukiman.

Sebagai dampak dari parameter nilai $\mathrm{C}$ yang meningkat, maka parameter Id akan menurun. Hal demikian terjadi pula di daerah penelitian, dan kondisi ini logis terjadi karena semakin berkurang daerah resapan air, maka tentunya imbuhan air (Id) ke dalam tanahpun semakin kecil.

Perhitungan imbuhan Id ini berfungsi untuk memperkirakan jumlah simpanan air dalam tanah pada wilayah tertentu. Bila perubahan Id dari waktu ke waktu semakin mengecil, berarti ada indikasi pengurangan pasokan air ke dalam tanah. Hal ini berarti segera perlu dilakukan pengelolaan sumberdaya air di wilayah yang bersangkutan. Seperti dengan cara pembuatan embong-embong, sumur resapan ataupun pembatasan alih fungsi lahan. Demikian pula yang terjadi di daerah penelitian, yang saat ini sudah terlihat adanya perununan nilai Id. Dengan demikian daerah penelitian perlu segera menangani problema ini secara serius.

Adapun parameter Wa umumnya mempunyai kecenderungan bertambah, sesuai atas peningkatan nilai $\mathrm{C}$, maka wajar bila Wa pun bertambah besar. Namun demikian terdapat perbedaan yang signifikan antara nilai C dan Wa. Nilai C lebih mencerminkan pada persentase jumlah curah hujan yang menjadi limpasan, sedangkan Wa merupakan aliran air permukaan yang bukan hanya berasal dari limpasan saja, tetapi juga disokong oleh aliran air tanah yang telah keluar dari dalam tanah sebagai air permukaan, sehingga demikian Wa merupakan sumber air permukaan yang tersedia secara aman sepanjang tahun.

Berdasarkan karakteristik 3 (tiga) parameter hidrologi tersebut, yang dalam hal

Tabel 6. Karakteristik Perubahan Parameter Hidrologi Daerah Penelitian

\begin{tabular}{|c|c|c|c|c|}
\hline No. & Kecamatan & $\begin{array}{c}C \\
\text { (dalam \%) }\end{array}$ & $\begin{array}{c}\text { Id } \\
\left(\mathrm{m}^{3} / \mathrm{tahum}\right)\end{array}$ & Wa \\
\hline 1. & Wexu & + & - & + \\
\hline 2. & Bulu & + & - & + \\
\hline 3. & 'Tawangs ati & + & - & + \\
\hline 4. & Sukohatjo & 0 & - & 0 \\
\hline 5. & Nguter & + & - & + \\
\hline 6. & Bendosati & + & - & + \\
\hline 7. & Polokatto & + & - & + \\
\hline 8. & Mojolaban & + & - & + \\
\hline 9. & Grogol & + & - & + \\
\hline 10. & Baki & 0 & - & 0 \\
\hline 11. & Gatak & 0 & - & 0 \\
\hline 12. & Kaxtasuro & + & - & + \\
\hline
\end{tabular}

Sumber: Anna, et al (2006) 
ini nilai $\mathrm{C}$ meningkat, Id menurun, dan Wa meningkat, maka dapat dikatakan bahwa alih fungsi lahan di daerah penelitian telah berdampak secara signifikan pada perubahan parameter hidrologinya. Akibat perubahan tersebut menyebabkan terjadi pengurangan air yang meresap dalam tanah. Walaupun demikian ternyata masih tersedia sumber air permukaan secara aman yang diindikasikan nilai Wa meningkat. Hal ini kemungkinan dikarenakan rasio antara permukaan lahan yang terbangun dengan permukaan lahan terbuka ( $>30 \%$ ) masih proporsional.

\section{KESIMPULAN DAN SARAN}

Hasil interpretasi Citra Landsat tahun 1997 dengan tahun 2002 ternyata daerah penelitian terdapat 7 macam pola alih fungsi lahan. Adapun alih fungsi lahan yang terluas umumnya dari lahan terbuka (sawah, tegalan hutan/perkebunan) menjadi lahan terbangun (permukiman/ gedung/sarana umum), sehingga mengakibatkan perubahan parameter hidrologi yang diteliti.

Dari 3 (tiga) parameter yang diteliti, ternyata nilai C (koefisien runoff) dan Wa (aliran mantap) mempunyai kecenderungan meningkat, sedangkan Id (imbuhan air alami) mempunyai kecenderungan menurun. Hal ini berarti alih fungsi lahan telah berdampak pada kenaikan limpasan dan menurunkan kapasitas air yang meresap dalam tanah. Namun demikian ternyata ketersediaan sumberdaya air wilayah secara umum masih dapat disokong dari jumlah aliran mantap yang cenderung meningkat. Kondisi demikian kemungkinan karena rasio lahan terbangun dengan lahan terbuka masih proporsional.

Rekomendasi penelitian ini antara lain 1) perlu mempertahankan rasio lahan terbangun dengan lahan terbuka secara proporsinal, agar kekritisan sumberdaya air di waktu mendatang dapat dihindarkan, 2) penataan kembali tentang tata ruang daerah penelitian, yang di dalamnya memuat adanya ruang untuk resapan air (seperti untuk embung, daerah resapan air khusus), dan 3) perlu dibuat peraturan melalui peraturan daerah mengenai kewajiban penduduk untuk membuat sumur resapan pada setiap bangunan yang akan dibangun/ dibuat.

\section{UCAPAN TERIMA KASIH}

Penelitian ini dapat terlaksana dengan lancar, karena bantuan dan kerjasama berbagai pihak. Oleh karenanya, penulis mengucapkan terimakasih kepada KPMPT Dirjen Dikti sebagai penyedia dana, PIC PHK-A2 Fakultas Geografi, komunitas 5W (Yudhi, Ipung, Washil, Dara, dan Riris), dan berbagai pihak yang telah memberi kesempatan tenaga dan waktu untuk mempertajam kemampuan akademis penulis.

\section{DAFTAR PUSTAKA}

Anna, A.N., et al (2006) Analisis Karakteristik Parameter Hidrologi Akibat Alih Fungsi Lahan di Daerah Sukoharjo Melalui Citra Landsat Tabun 1997 dengan Tabun 2002. Surakarta: Fakultas Geografi UMS. 
Anna, A. N. (2001) Agihan Kualitas Air Tanah Daerah Perkembangan Kota Antara Surakarta - Kartasura. Forum Geografi. vol. 15, no. 1, Juli.

Arpan. F., Galuh, C.K.D., dan Sudjarwadi (2004) Kajian Meteorologis Hubungan Abtara Hujan Harian Dan Unsur-unsur Cuaca: Studi Kasus di Stasiun Meteorologi Adisucipto Jogjakarta. Majalab Geografi Indonesia, vol. 18, no. 2, September.

Hadi, M.P. dan Endarmiyati (1999) Model Perhitungan Indeks Kekritisan Air, Studi Kasus DAS Kreo. Geosfer, vol. 1, Oktober.

Muhsinatun (2000) 'Defisit Air Jawa-Madura Sangat Serius'. Solopos, 23 Maret.

Pemerintah Kabupaten Sukoharjo (2000) Neraca Sumberdaya Alam Daerah Kabupaten Sukoharjo Tabun 1999. Sukoharjo: Bappeda

Danoedoro, P. (1996) Pengolahan Citra Digital Teori dan Aplikasinya Dalam Bidang Penginderaan Jauh.Diktat Kuliah. Yogjakarta:Fakultas Geografi UGM.

Laviani, R., et al (2003) Pengaruh Kondisi Sosial Ekonomi Penduduk dan Perubahan Jenis Penggunaan Lahan Terhadap Limpasan Di DAS Bodri Kendal Jawa Tengah. Forum Geografi, vol. 17, no. 1, Juli.

Nugroho, S. (2006) Penggunaan Citra Landsat untuk Mengetahui Perubahan Penggunaan Lahan Di Sebagian Wilayah Subosuka. Skripsi. Surakarta:Fakultas Geografi UMS

Soetikno. 1989. Studi Geomorfologi untuk. Evaluasi Sistem Penyediaan Air Bersib di DAS Serang Kulon Progo. Yogjakarta: Fakultas Geografi UGM.

Suyono. 1995. Pengelolaan Sumberdaya Air. Jogjakarta: Fakultas Geografi UGM.

Suyono. 1996. Pengelolaan Daerah Aliran Sumngai Dalam Konteks Hidrologi Dan Kaitannya Dengan Pembangunan Berkelanjutan. Pidato Pengukuban Jabatan Lektor Kepala Madya Pada Fakultas Geografi UGM. Jogjakarta: Fakultas Geografi UGM.

Murtiono, U.H., et al (2001). Studi Karakteristik Hujan Dan Regim Sungai DAS. Laporan Penelitian. Surakarta: Balai Teknologi Pengelolaan DAS Departemen Kehutanan. 